\title{
Representations of voluntary childlessness in the UK press, 1990-2008
}

(abstract)

Representations of voluntary childlessness - the declaration by an individual that he or she does not wish to bear or raise children - were studied in 116 articles published in British national newspapers in the period 1990-2008. Media framing analysis (Shaw \& Giles, 2009) was used to examine broad patterns of framing of the topic, identifying four frames: voluntary childlessness as an individual rights issue, as a form of resistance, as a social trend, and as a personal decision. A microanalysis of 14 selected feature articles demonstrated the power of the individual rights frame, which was found to occasionally override the other frames even in traditionally conservative news sources. These frames, it is argued, may act as potential 'scripts' for newspaper readers who are debating the decision to start a family.

Final version of published article: Giles, D.C,. Shaw, R.L. \& Morgan, W. (2009). Representaions of voluntary childlessness in the UK Press, 1990-2008. Journal of Health Psychology, 14(8), 1218-1228. 
(introduction)

Voluntary childlessness - the declaration by an individual that he or she does not wish to bear or raise children - has developed a small academic literature over recent years and has become a popular discussion topic in various media. Along with the growing tendency to 'postpone' motherhood, voluntary childlessness has occasionally been characterised as symptomatic of selfish, uncaring individualism, at other times as a symbol of feminist liberation, with 'childfree' women celebrating their rejection of the "motherhood mandate" (Russo, 1976). In this study we analysed the content of British newspapers over the last two decades to examine the frames made available for understanding voluntary childlessness that might act as 'scripts' for a contemporary media audience.

Voluntary childlessness first emerged as a social phenomenon as a political stance in the United States in the 1970s, with the publication of Ellen Peck's The Baby Trap (1971) and the formation of the National Organisation for Non-Parents, a campaigning body that attracted up to 2000 members at its peak (Park, 2002). In the intervening decades, studies have indicated a slow but gradual increase in the numbers of women describing themselves as voluntarily or intentionally childless in Europe, Australia and the United States (Abma \& Martinez, 2006; Dykstra \& Hagestad, 2007; Lee \& Gramotnev, 2006). The US figures rose from 2 per cent in 1966 to 6 per cent in 1988 (Rovi, 1994). More recently, figures of 11 and 12 per cent have been cited for German and British men and women under 30 (Hakim, 2003).

Final version of published article: Giles, D.C,. Shaw, R.L. \& Morgan, W. (2009). Representaions of voluntary childlessness in the UK Press, 1990-2008. Journal of Health Psychology, 14(8), 1218-1228. 
These trends have been reinforced by declining fertility rates and increasing 'postponement' of motherhood in many Western societies. During 2000-2005, the UK fertility rate fell to 1.79 children per woman compared with 2.04 during the 1970-75 period (United Nations, 2006). Even greater decreases were observed in Italy and Spain (from 2.33 and 2.86 respectively to just 1.29 in the same periods). These figures indicate that many societies are currently well below their population replacement levels, estimated to be 2.1 children per woman in the 'developed' world (Espenshade, Guzman \& Westoff, 2003).

Declining fertility rates have been addressed in government policy: for example, in the UK, the Labour government has strengthened its Working Families policy through measures such as family tax credit schemes and increased maternity and paternity leave (HMSO, 2006). Recent years have shown a slight increase in fertility in the UK, although there is some variation across fertility rates in different age groups. Notably the biggest increases have been seen in the 30-35 age group. The average age for a woman giving birth to her first child in 2007 was 29.3 (Office for National Statistics, 2008). It has been argued that figures of declared voluntary childlessness actually underestimate the number of women who will never give birth, since they do not contain any information about actual fertility (Dykstra \& Hagestad, 2007).

Changing fertility patterns, along with a number of books promoting the benefits of childlessness, are reflected by increasing media interest in the topic, which have typically characterised it as a historical phenomenon, symbolising both female independence and capitalist individualism (Lee \& Gramotnev, 2006). Some authors have challenged this interpretation, arguing that the apparent trend in voluntary Final version of published article: Giles, D.C,. Shaw, R.L. \& Morgan, W. (2009). Representaions of voluntary childlessness in the UK Press, 1990-2008. Journal of Health Psychology, 14(8), 1218-1228. 
childlessness is a 'myth’ (Lee \& Gramotnev, 2006), and that it is wrongly blamed on historical factors (Rowland, 2007). The later shortfall in births can be better explained by women postponing, rather than deciding firmly against, motherhood, and experiencing declining fertility as a consequence (Rowland, 2007). In one longitudinal study it was found that 25 per cent of women who had initially declared themselves voluntarily childless subsequently gave birth, typically because they had married during the interim (Heaton, Jacobson \& Holland, 1999).

Whatever the social explanations, there are still a number of negative attributions made about those who choose not to have children. Compared with parents of varying sizes of family and the involuntarily childless (typically characterised as infertile), voluntarily childless individuals have been rated as immature, selfish, cold, and less likely to enjoy favourable life circumstances (Kopper \& Smith, 2001; Mueller \& Yoder, 1997; LaMastro, 2001; Lampman \& Dowling-Guyer, 1995). A somewhat more positive picture was drawn in a study by Koropeckyj-Cox \& Pendell (2007), who argued that acceptance, if not endorsement, was the prevailing attitude, but this study failed to differentiate voluntary from involuntary childlessness.

Negative attributions towards childlessness are not confined to the wider population. An interview study with voluntarily childless individuals found that they believed themselves to be regarded as selfish and materialistic, and that some even pretended to be delaying motherhood to family and friends in order to deflect negative comments (Park, 2002). In a separate interview study, voluntarily childless women gave a variety of reasons for their decision, ranging from a general lack of interest in children to the desire to continue an enjoyable single lifestyle and even to a wish not Final version of published article: Giles, D.C,. Shaw, R.L. \& Morgan, W. (2009). Representaions of voluntary childlessness in the UK Press, 1990-2008. Journal of Health Psychology, 14(8), 1218-1228. 
to contribute to world overpopulation. A few gave negative reasons, typically bad experiences of their own childhood (Park, 2005).

It has been argued that childless individuals experience negative responses to their decision because it violates the norm of parenthood that characterises most societies: it is "not in accordance with the standard script” (Dykstra \& Hagestad, 2007, p.1277). Childless women, in particular, are therefore expected to provide a rationale.

In the present study we have chosen to examine some of the most prevalent (alternative) scripts that are available for women in contemporary British society: media representations of voluntary childlessness. The topic has featured widely over the last two decades in the British press in discourses around social change and diverse models of parenting and family structure. We explore these through the perspective of media framing, informed by the work of communication scholars in recent decades (Entman, 1991, 1993; Gamson \& Modigliani, 1989; Pan \& Kosicki, 1993; van Gorp, 2007) and our own attempts to develop a systematic analytic procedure for carrying out this kind of research, MFA (media framing analysis; Giles \& Shaw, 2009; Shaw \& Giles, 2009).

Media frames have been described as “interpretive packages” (Gamson \& Modigliani, 1989, p.2); selective ways of presenting reality in order to promote a particular interpretation or moral evaluation (Entman, 1993). The framing process can be, and has been, studied from a multitude of perspectives, both theoretical and disciplinary (see Scheufele, 1999 for a critical overview). Our own perspective is informed partly by social constructionism and discourse analysis, but also by cognitive psychology: as Final version of published article: Giles, D.C,. Shaw, R.L. \& Morgan, W. (2009). Representaions of voluntary childlessness in the UK Press, 1990-2008. Journal of Health Psychology, 14(8), 1218-1228. 
van Dijk (2006) argues, it is essential to consider processes of persuasion and manipulation if we are to understand how discourse is used to influence public opinion. One way this is accomplished is by inviting the audience to identify with the human subjects of news stories, and the narrative study of character is an important component in our analytic procedure.

Our analysis of the media coverage of voluntary childlessness was conducted in two clear phases: a broad analysis of the coverage in British newspapers over the last two decades that provides a general impression of how the issue has been framed; and a micro-analysis of a small number of selected texts drawn from this corpus that illustrates the persuasive work accomplished by framing processes.

\section{Data collection}

Media materials on the topic of childlessness from the 1990-2008 period were gathered from a number of databases as part of a larger project. In this paper, the specific focus is on newspaper articles, which were identified by entering a series of combinations of search terms (see appendix 1) into the LexisNexis database of British national and regional newspapers.

The resulting 142 articles were then classified according to the genre of article. We began by distinguishing 'long feature items' from 'short feature items' on the basis of word length, using 1500 words as a cut-off point. Long feature items are typically found in the centre of the newspaper, occupying at least a page. Short feature items, which comprised the largest genre are often found nearer the front page; the Final version of published article: Giles, D.C,. Shaw, R.L. \& Morgan, W. (2009). Representaions of voluntary childlessness in the UK Press, 1990-2008. Journal of Health Psychology, 14(8), 1218-1228. 
distinction between extended news item and short feature is hard to define, although we used a length of 500 words as a cut-off point.

Other than word length, long features are distinguished from short ones in that they include more elaborate descriptions of their chosen individuals, often first-hand accounts. A typical short feature focuses on 5-10 quoted individuals, who have been selected in order to provide evidence for a generalised phenomenon (in this instance, voluntary childlessness). In the sample as a whole there were considerably more short features ( $n=73$, almost half the sample) than long features $(n=39)$.

News items are characterised by: a) simple, 'factual' headlines; b) short paragraphs, often consisting of a single sentence; c) relatively little quotation, and d) a clear news peg (e.g. “The Bishop of Rochester said yesterday that...” or “a study released yesterday showed that...”). The small number of news items in our sample $(n=12)$ reflects the fact that coverage of childlessness tended to be confined to more discursive, commentary-type articles rather than direct reportage. Indeed there were more letters $(n=14)$ in the sample, typically in response to previous feature items. The remaining three articles consisted of two book reviews (books also provided the 'peg' for many of the features), and a column (i.e., a regular column written by a 'celebrity’ journalist).

\section{Macroanalysis of frames}

Final version of published article: Giles, D.C,. Shaw, R.L. \& Morgan, W. (2009). Representaions of voluntary childlessness in the UK Press, 1990-2008. Journal of Health Psychology, 14(8), 1218-1228. 
An initial media framing analysis (MFA; Shaw \& Giles, 2009) was conducted on the full data set with the intention of identifying a consistent set of frames that the British press had made available to readers over the last two decades.

One of the first tasks in a framing analysis is to identify the 'news peg' of each article: this is a specific event, or incident, that can be regarded as a trigger for that particular article (Cooper \& Yukimura, 2002). Sometimes the 'news peg' itself is another media source: many short features are triggered simply by news items from previous days (Shaw \& Giles, 2009).

Our analysis identified seven categories of news peg, some relating to specific events, such as the publication of a particular study or book, others consisting of a broad class of events. Table 1 lists these in terms of prevalence within the sample. The majority of stories (56.8\%) were generated by the publication of official reports of research (e.g., academic publications or market research), while the second most common news peg, publication of books or TV appearances by childfree individuals, accounted for only $16.9 \%$ of the sample.

---Table 1 here---

Focusing on the feature articles and longer news items in the sample $(n=116)$, we identified a broad frame that best characterised each article - for example, "childless by default" - in order to construct an overall impression of the available frames in the data set. This was done using an iterative process typical of thematic analysis (Braun \& Clarke, 2006), in that similar frames were clustered together in order to produce a Final version of published article: Giles, D.C,. Shaw, R.L. \& Morgan, W. (2009). Representaions of voluntary childlessness in the UK Press, 1990-2008. Journal of Health Psychology, 14(8), 1218-1228. 
set of 15 frames that best characterised the sample. This was then further reduced to a superordinate list of four broad framing tendencies - voluntary childlessness as an individual human rights issue, as a form of resistance to social norms, as a symptom of broader social change, and as a personal decision.

The complete list of frames is presented in table 2 along with a brief description of each specific frame. Frequency values indicate that an individual rights frame was the most prevalent, accounting for $43.1 \%$ of the articles in the sample. A three-way loglinear analysis found that the association between frame, article type and news peg was significantly different from zero $\left(\chi^{2}(3)=8.65, p=.03\right)$. The rights frame was most commonly associated with short features relating to a research publication news peg.

Analyses were conducted on the source of the articles, which found that the Times was the major contributor, with 26 articles overall (39 if including those appearing in the Sunday Times), closely followed by the Guardian (25, plus another 8 from its Sunday paper the Observer) and the Independent (19). The distribution of articles differed somewhat by frame, with a social change frame more likely to be favoured by the Guardian than the Times, and a resistance frame most commonly presented by the Times. However, a chi-square test of Guardian/Observer frames against Times/Sunday Times frames failed to find any significance for this pattern $\left(\chi^{2}(3)=\right.$ $3.74, p>.05)$.

A further analysis was conducted on the article headlines in terms of their framing properties. Headlines were coded as positive, neutral or negative according to the light Final version of published article: Giles, D.C,. Shaw, R.L. \& Morgan, W. (2009). Representaions of voluntary childlessness in the UK Press, 1990-2008. Journal of Health Psychology, 14(8), 1218-1228. 
in which they presented voluntary childlessness. For example, within the 'resistance' frame the headline “Don’t drag children into office politics” was coded as negative because it implies criticism of childless workers' complaints about workplace bias in favour of parents. The headline "Welcome to the new divide" was coded as positive because it appears to favour the opposing view (that parents and childfree workers have different priorities and - by implication - should receive equal treatment). Headlines were coded as neutral if they lacked any emotive terms (e.g., “flying solo”).

A chi-square analysis found that positive headlines were more strongly associated with rights frames while negative frames were more associated with social change frames $\left(\chi^{2}(6)=20.13, p=.003\right)$. A breakdown of this data by source indicated that most of the positive rights-related headlines appeared in the Guardian and the Independent, while a notable cluster of negative 'rights' headlines appeared in the Daily Mail. The majority of negative social change headlines appeared in the Guardian and Independent. Other observations of interest include the finding that the resistance-framed articles included only three neutral headlines (out of 28), and personal frames included only one negative headline (out of 14).

Finally, analysis of the timeline of articles found that only 6 per cent of the sample was published prior to 1995. From 1995 to 2008 there was little year-on-year variation in coverage, apart from a slight peak in the 2002-2003 period, during which 25 per cent of the sample was published.

\section{Microanalysis of selected articles}

Final version of published article: Giles, D.C,. Shaw, R.L. \& Morgan, W. (2009). Representaions of voluntary childlessness in the UK Press, 1990-2008. Journal of Health Psychology, 14(8), 1218-1228. 
The second part of the framing analysis involved the close analysis of a selected number of articles about voluntary childlessness. Rather than focusing on a type of frame identified in the macroanalysis, we chose to explore a broad category of article that seemed particularly pertinent to the research aim of identifying available 'scripts' for voluntary childlessness.

The articles chosen for the microanalysis were a mixture of long and short features written in the first person, in which the author made a declaration that he or she is childless or childfree. We avoided ostensibly objective articles that were written in the third person, consisting largely of quotations, which characterised a large number of features (particularly the shorter ones). Despite this, the two longest articles in the set included a large number of interview quotes, where the childfree author had interviewed a variety of similarly childless individuals. Nevertheless, the main criterion was that the authorial voice was consistently first person childfree throughout.

We ended up with a total of 14 articles, covering a broad spread of sources, most from the latter half of the period covered in the macroanalysis. Original copies of the articles were obtained from the British Library in order to study their contextual features (pictures, headlines, captions, position in publication). In most instances where it was possible to identify a specific news peg, this was the publication of a book (typically one that the author had written themselves, or had contributed to). Two exceptions to this pattern were published in 2005 in the (right-wing) Daily Telegraph, where the 'peg' in each case appears to be the Labour government's proposed family tax credit scheme. Final version of published article: Giles, D.C,. Shaw, R.L. \& Morgan, W. (2009). Representaions of voluntary childlessness in the UK Press, 1990-2008. Journal of Health Psychology, 14(8), 1218-1228. 
The following analysis of these articles enables us to examine more closely the four broad frames identified in the macroanalysis. Several key features of framing analysis were considered here: the narrative structure of the articles, the characterisation, with particular emphasis on reader identification with the author, and the use of specific language terms as membership categories (Shaw \& Giles, 2009).

Close scrutiny of this particular subset of articles revealed that the macroanalysis masks a number of interesting sub-themes that underpin the broader frames. The 'rights' frame was considered the dominant frame in seven of the 14 articles, and, despite their sharing many of the same characteristics, we had coded five of the 14 as 'resistance' because the authors were more emphatic about their opposition to anticipated or expected normative behaviour. Many of the articles were structured as polemics, with a series of (parenthood) arguments alternating with (childfree) counter-arguments.

Most of the 14 articles were stridently individualistic, with the word "I" appearing as the first word (of the actual text) in five of the articles, in the first sentence of five further articles, and in the second sentence of a further three. Of the remaining two, one was written by a male author - the only one in the sample. Only two authors, when referring to their decision to remain childfree, used the first person plural.

Here we have chosen to concentrate on a selection of sub-themes that could act as potential 'scripts' for voluntary childlessness. The numbers in brackets refer to the articles, listed in chronological publication order. Final version of published article: Giles, D.C,. Shaw, R.L. \& Morgan, W. (2009). Representaions of voluntary childlessness in the UK Press, 1990-2008. Journal of Health Psychology, 14(8), 1218-1228. 
Children as hobby: A matter of choice

A powerful theme within these articles is the notion of choice, with motherhood and childlessness framed as two possible options available for women, typically presented as vocational. Some authors state this explicitly ("The key word here is 'choice”(4)). "Motherhood is not a job I ever wanted”, states one author (9). "Nappies are not for me", runs one headline (3), while another, in similar vein, introduces "five [women] who chose happiness over nappiness" (7). The decision to be childfree is frequently justified through listing ways in which motherhood might limit choice ("we travel a lot and enjoy the flexibility of popping out for a meal or to the cinema") (8); "I travel frequently... and at a few hours' notice” (3).

The sense of motherhood/childlessness as choice is reflected in three other themes that recur in the 'rights'-framed articles. The first, children as nuisance, dwells on those aspects of mothering that might be thought of as unpleasant or inconvenient dealing with infant bodily functions, or the noise, untidiness, and general disruption to the adult home of toddlers and older children. Imagery around nappies is frequent. One author admits to having a visceral dislike of babies: “That wet and dribbling dependency, the milky smell, the soft, questing mouth find revulsion in me” (7). Several authors contrast the seemingly endearing appeal of babies with the "reality" of child care, suggesting that parents have a tendency to overplay the former, even while dwelling on the messy aspects. "Never, ever, imagine we'll be impressed by a description of the contents of your baby's nappy”, ends one article (8).

Final version of published article: Giles, D.C,. Shaw, R.L. \& Morgan, W. (2009). Representaions of voluntary childlessness in the UK Press, 1990-2008. Journal of Health Psychology, 14(8), 1218-1228. 
Visually, picture editors made occasional use of the children-as-messy theme. In Figure 1, Jan Masters (13) is photographed behind two children’s toys, a giant toy train engine and a tricycle, which have been placed apart in a haphazard fashion in order to suggest the (absent) untidiness of their young owners. In Figure 2, more graphically, an infant is photographed from beneath, mouth agape, in stark lighting, producing an almost demonic effect. The caption - a direct quote from the text reads: "The nappies, the shrieking, the penury, the career stagnation all fill me with horror" (5).

The second choice-related theme is child substitutes, which features in several of the articles where women discuss the possibility that other activities serve as substitutes for child rearing. The substitutes are often spoken of as receptacles for either love or fulfilment ("my love goes into my paintings" (7); "it is possible to find love and fulfilment from other sources” (8)). Rose Shepherd's article in The Guardian features five childless individuals (7), several of whom are pictured alongside an object of devotion which is by implication a child-alternative: a dog, a painting, an art gallery. Childlessness is framed explicitly as a "choice”, based unashamedly on “inclination".

The concept of "family" is challenged by several authors, arguing that it is possible to construct a family without children. Dogs are mentioned frequently, often defensively, as stereotyped substitute material: “And then, of course, I have a dog. The mummy mafia smile knowingly, and diagnose a child substitute.” (9).

Finally, poor choice of mate is used as an explanation by several authors. Jan Masters's article carries the highlighted quote "I just never reached the let's-makeFinal version of published article: Giles, D.C,. Shaw, R.L. \& Morgan, W. (2009). Representaions of voluntary childlessness in the UK Press, 1990-2008. Journal of Health Psychology, 14(8), 1218-1228. 
babies stage with anyone”, citing a fatal attraction to 'alpha males' as the reason (13). One woman interviewed simply did not want to commit to "Mr Not Quite Right", while admitting a subsequent pang of regret (11).

Sarah Churchwell's article (14) in the Daily Mail in 2008 is interesting given that the paper had up to that point been highly critical of voluntary childlessness. In it, she lists the inadequacies of the various potential fathers who have failed to make the grade over the years (“ $a$ string of disastrous men” - rather than disastrous relationships), and argues that it is difficult to contemplate the idea of motherhood without assuming the dominant identity of mother. The article ends with an italicised footnote which asks the reader: “Do you agree with Sarah?” along with an e-mail address requesting views and opinions. Even the Daily Mail is comfortable with the idea of voluntary childlessness when framed as a choice, and a matter of individual rights.

Mothering as 'unnatural'

This next sub-theme is effectively a continuation of the first, whereby the choice not to have children is justified by authors' claims that they are unsuited to the vocation of motherhood. For some, this is seen as a skills-based issue: "I doubted that I had a talent for it" (7). For others, the disinclination towards parenting has more profound origins. "Most people, and especially most women, have a physiological yearning to reproduce”, wrote one (5), quoting the author of ‘The Childless Revolution’ who claims, on the basis of experimentation with mice, that there is actually a genetic basis 
for nurturing; or at least one that differentiates between individuals on this characteristic.

The idea that women differ in their natural suitability for mothering is reflected in some of the more bitter exchanges with mothers reported in the articles, and typically the (felt) accusation that childless women are unable to share their grief at tragic news stories involving children. These comments "hurt the most” (13). Other authors emphasise a "growing divide" (8) between parents and nonparents, especially in the workplace.

The notion of motherhood as a vocation is juxtaposed by several authors with their alternative vocations. A professional writer claims, "had I had children I would have written no books" (11). The concern that authors might be fundamentally unsuited to mothering is countered on several occasions by anecdotal asides in the articles where fulfilling experiences with young relatives or friend's children are recounted, in great detail. “[My niece and I] managed to sing an alphabet song 127 times” writes Sarah Churchwell (14), wondering whether this ‘devotion’ means that “maybe I am mother material after all”. While the article as a whole is framed as resistance, the ending leaves open the possibility of children.

Selfishness: good or bad?

A recurrent theme throughout the articles in the database as a whole is that of selfishness. Typically an author or interviewee will cite selfishness as an accusation levelled at the voluntarily childless: "labelled selfish and unnatural” (8); Final version of published article: Giles, D.C,. Shaw, R.L. \& Morgan, W. (2009). Representaions of voluntary childlessness in the UK Press, 1990-2008. Journal of Health Psychology, 14(8), 1218-1228. 
“Does this make me selfish?” (7). In many articles, the accusation is reversed and turned on parents: "parents can be just as selfish when acting in the interests of their family” (12); "Some parents are driven by narcissism, in search of a 'mini-me' child who will fulfil the dreams that eluded them" (14). Alternatively, a number of authors re-frame selfishness positively, as a synonym for individuality and freedom: “I never wanted them, and I am grateful to be able to exercise my choice” (9). There is an underlying tension between social responsibility and personal freedom, occasionally linked to feminism; one author even claiming that "mothers hijack the language of feminism and femininity” (6).

Demographics: Gender, class and ethnicity

One final sub-theme concerns the "larger social picture" (11) in which individual choice is seen to symbolise broader trends. The authors of these articles, mostly white middle-class Europeans and Americans, express guilt from time to time that they are depriving future generations their genes. One says, with a tinge of irony, "if people like me don't reproduce, society will be the worse for it", although the author of the piece, novelist Lionel Shriver, develops a powerful argument that the real concern around the "selfishness" levelled at childless people, and their corresponding guilt, are driven by white middle-class fears that they are demographically unusual in their disinclination for children. As Shriver puts it, white middle-class Europeans and Americans are not prepared for the hard work of parenting simply because children “might not make us happy” (11). Without any economic need for children, it is suggested, this demographic sector risks eventual extinction.

Final version of published article: Giles, D.C,. Shaw, R.L. \& Morgan, W. (2009). Representaions of voluntary childlessness in the UK Press, 1990-2008. Journal of Health Psychology, 14(8), 1218-1228. 


\section{Discussion}

This study set out with the aim of charting UK press coverage, mostly in newspapers, of voluntary childlessness throughout two decades. The first aim was to identify a set of 'frames' by which different articles had presented the subject of childlessness. Our initial expectation was that voluntary childlessness (VC) would be framed in a largely critical way, although in our macroanalysis of the data set as a whole we found a more subtle framing process, whereby critical frames tended to be those which presented VC as a social trend (either as rampant individualism, or as selfish indulgence), while positive frames were associated with individual rights arguments, with VC defended as freedom of choice, occasionally with a post-feminist slant.

A further microanalysis explored some of the scripts that the media coverage of VC might make available for childless individuals in general. Fourteen articles were selected for reasons of homogeneity (as first-person confessional accounts of VC). The frames that these articles received as part of the macroanalysis were found to encompass a number of related sub-themes around children as a lifestyle choice, motherhood as a vocation, ambivalence around accusations of selfishness, and occasional broader glimpses of the broader social picture. Nevertheless, the rights frame emerged as the most powerful in general, overriding other frames even in the most conservative of news sources.

Some of the first person anecdotal accounts carried a tinge of misanthropy, with children being demonised; one even reinforced the notion of children as commodities by photographing the author surrounded by designer items along with a corresponding Final version of published article: Giles, D.C,. Shaw, R.L. \& Morgan, W. (2009). Representaions of voluntary childlessness in the UK Press, 1990-2008. Journal of Health Psychology, 14(8), 1218-1228. 
price list. However, others, notably a piece by the author Lionel Shriver, acknowledged the veiled ethnocentrism behind much of the criticism of voluntarily childless mothers. Elsewhere, a list of reasons for VC was occasionally countered by a series of positive anecdotal experiences with children, leaving open the possibility of motherhood after all. While framed as defiant and proud childlessness, such articles might also be read as about 'delayed motherhood' rather than childlessness per se.

There is still uncertainty about the actual impact of framing on media audiences (Giles \& Shaw, 2009; Scheufele, 2004). We argue that the frames here may act as potential 'scripts' for newspaper readers who are debating the decision to start a family. A next stage in voluntary childlessness research might be to see how persuasive these frames - and the rights argument in particular - might be in a casual discursive social context such as in the accounts posted on discussion forums described as a haven for those who are childfree by choice.

In short, this study has shown that voluntary childlessness is a phenomenon which warrants social comment; the formulation of message frames in the popular press confirms that choosing not to have children is an issue of concern in contemporary Britain. Our analyses have revealed that choosing to remain childless is no simple matter with frames identified indicating both scepticism and support.

\section{References}

Abma, J.C., \& Martinez, G.M. (2006). Childlessness among older women in the United States: Trends and profiles. Journal of Marriage and Family, 68, 1045-1056. Final version of published article: Giles, D.C,. Shaw, R.L. \& Morgan, W. (2009). Representaions of voluntary childlessness in the UK Press, 1990-2008. Journal of Health Psychology, 14(8), 1218-1228. 
Braun, V., \& Clarke, V. (2006). Using thematic analysis in psychology. Qualitative Research in Psychology, 3, 77-101.

Cooper, C.P., \& Yukimura, D. (2002). Science writers’ reactions to a medical “breakthrough”' story. Social Science and Medicine, 54, 1887-1896.

Dykstra, P.A., \& Hagestad, G.O. (2007). Roads less taken: Developing a nuanced view of older adults without children. Journal of Family Issues, 28, 1275-1310.

Entman, R. M. (1991). Framing U.S. coverage of international news: Contrasts in narratives of the KAL and Iran air incidents. Journal of Communication, 41, 6-27.

Entman, R. M. (1993). Framing: Towards clarification of a fractured paradigm. Journal of Communication, 43, 51-58.

Espenshade, T.J., Guzman, J.C., \& Westoff, C.F. (2003). The surprising global variation in replacement fertility. Population Research and Policy Review, 22, 575583.

Gamson, W., \& Modigliani, A. (1989). Media discourse as a symbolic contest: A constructionist approach. American Journal of Sociology, 95, 1-37.

Final version of published article: Giles, D.C,. Shaw, R.L. \& Morgan, W. (2009). Representaions of voluntary childlessness in the UK Press, 1990-2008. Journal of Health Psychology, 14(8), 1218-1228. 
Giles, D.C., \& Shaw, R.L. (2009; in press). The psychology of news influence and the development of Media Framing Analysis. Social and Personality Psychology Compass.

Hakim, C. (2003). Public morality versus personal choice: The failure of social attitude surveys. British Journal of Sociology, 54, 339-345.

Heaton, T. B., Jacobson, C. K., \& Holland, K. (1999). Persistence and change in decisions to remain childless. Journal of Marriage and Family, 61, 531-539.

HMSO (2006). Work and Families Act 2006. London: The Stationery Office Ltd.

Kopper, B. A., \& Smith, M. S. (2001). Knowledge and attitudes toward infertility and childless couples. Journal of Applied Social Psychology, 31, 2275-2291.

Koropeckjyj-Cox, T., \& Pendell, G. (2007). Attitudes about childlessness in the United States: Correlates of positive, neutral, and negative responses. Journal of Family Issues, 28, 1054-1082.

Lampman, C., \& Dowling-Guyer, S. (1995). Attitudes towards voluntary and involuntary childlessness. Basic and Applied Social Psychology, 17, 213-222.

LaMastro, V. (2001). Childless by choice? Attributions and attitudes concerning family size. Social Behavior and Personality, 29, 231-244.

Final version of published article: Giles, D.C,. Shaw, R.L. \& Morgan, W. (2009). Representaions of voluntary childlessness in the UK Press, 1990-2008. Journal of Health Psychology, 14(8), 1218-1228. 
Lee, C., \& Gramotnev, H. (2006). Motherhood plans among young Australian women: Who wants children these days? Journal of Health Psychology, 11, 5-20.

Mueller, K.A., \& Yoder, J.D. (1997). Gendered norms for family size, employment, and occupation: Are there personal costs for violating them? Sex Roles, 36, 207-220.

Office for National Statistics (2008). National Statistics online, Population. Retrieved 12 December 2008 from http://www.statistics.gov.uk/cci/nugget.asp?id=369

Pan, Z. P., \& Kosicki, G. M. (1993). Framing analysis: An approach to news discourse. Political Communication, 10, 55-75.

Park, K. (2002). Stigma management among the voluntarily childless. Sociological Perspectives, 45, 21-45.

Park, K. (2005). Choosing childlessness: Weber's typology of action and motives of the voluntarily childless. Sociological Inquiry, 75, 372-402.

Peck, E. (1971). The baby trap. New York: B. Geis Associates.

Rovi, S. (1994). Taking “NO” for an answer: Using negative reproductive intentions to study the childless/childfree. Population Research and Policy Review, 13, 343-365.

Rowland, D.T. (2007). Historical trends in childlessness. Journal of Family Issues, 28, 1311-1337.

Final version of published article: Giles, D.C,. Shaw, R.L. \& Morgan, W. (2009). Representaions of voluntary childlessness in the UK Press, 1990-2008. Journal of Health Psychology, 14(8), 1218-1228. 
Russo, N. (1976). The motherhood mandate. Journal of Social Issues, 32, 143-179.

Scheufele, D. (1999). Framing as a theory of media effects. Journal of Communication, 49, 103-122.

Shaw, R.L., \& Giles, D.C. (2009; in press). Motherhood on ice? A media framing analysis of older mothers in the UK news. Psychology \& Health.

United Nations, Department of Economic and Social Affairs, Population

Division (2007). World Population Prospects: The 2006 Revision.

Working Paper No. ESA/P/WP.202.

Van Dijk, T.A. (2006). Discourse and manipulation. Discourse \& Society, 17, 359383.

Van Gorp, B. (2007). The constructionist approach to framing: Bringing culture back in. Journal of Communication, 57, 60-78.

Final version of published article: Giles, D.C,. Shaw, R.L. \& Morgan, W. (2009). Representaions of voluntary childlessness in the UK Press, 1990-2008. Journal of Health Psychology, 14(8), 1218-1228. 
Appendix 1: List of authors and sources of 14 articles selected for microanalysis

1 Joan Smith, The Independent, 28/01/96

2 Jasper Gerrard, The Independent, 24/05/00

3 Lindsey Hilsum, The Guardian, 16/08/02

4 Laura Marcus, The Guardian, 22/08/02

5 Michelle Goldberg, The Guardian, 11/8/03

6 Zoe Williams, The Guardian, 18/10/03

7 Rose Shepherd, The Observer, 19/10/03

8 Nicki Defago, Daily Express, 12/5/05

9 Kate Battersby, Daily Telegraph, 26/5/05

10 Laura Thompson, The Daily Telegraph, 06/08/05

11 Lionel Shriver, The Observer, 17/09/05

12 Gwyneth Lewis, The Guardian, 17/12/05

13 Jan Masters, The Observer, 12/3/06

14 Sarah Churchwell, Daily Mail, 5/6/08

Final version of published article: Giles, D.C,. Shaw, R.L. \& Morgan, W. (2009). Representaions of voluntary childlessness in the UK Press, 1990-2008. Journal of Health Psychology, 14(8), 1218-1228. 
Appendix 2. List of search terms entered into Lexis Nexis

\begin{tabular}{|c|c|c|}
\hline Search \# & Search terms & Search results \\
\hline 4 & procreator* & $\begin{array}{l}\text { National - } 36 \\
\text { Regional - } 24\end{array}$ \\
\hline 9 & $\begin{array}{l}\text { [voluntary OR elective] AND [childless! OR } \\
\text { childfree] }\end{array}$ & $\begin{array}{l}\text { National - } 342 \\
\text { Regional - } 139\end{array}$ \\
\hline 11 & childfree AND choice & $\begin{array}{l}\text { National - } 81 \\
\text { Regional - } 34\end{array}$ \\
\hline 12 & breeder* AND [childless! OR childfree] & $\begin{array}{l}\text { National - } 49 \\
\text { Regional - } 9\end{array}$ \\
\hline 16 & $\begin{array}{l}\text { [childfree OR childless!] SAME SENTENCE } \\
\text { [choice OR happy OR content] }\end{array}$ & $\begin{array}{l}\text { National - } 421 \\
\text { Regional - } 150\end{array}$ \\
\hline 17 & childless-by-choice & $\begin{array}{l}\text { National - } 45 \\
\text { Regional - } 15\end{array}$ \\
\hline 18 & Bishop of Rochester AND self-indulgent & $\begin{array}{l}\text { National - } 18 \\
\text { Regional - } 24\end{array}$ \\
\hline
\end{tabular}

Final version of published article: Giles, D.C,. Shaw, R.L. \& Morgan, W. (2009). Representaions of voluntary childlessness in the UK Press, 1990-2008. Journal of Health Psychology, 14(8), 1218-1228. 


\section{Figure captions}

Figure 1. Visual accompaniment to Jan Masters, The Observer, 12/3/06 (article \#13)

Figure 2. Visual accompaniment to Michelle Goldberg, The Guardian, 11/8/03

(article \#5)

Final version of published article: Giles, D.C,. Shaw, R.L. \& Morgan, W. (2009). Representaions of voluntary childlessness in the UK Press, 1990-2008. Journal of Health Psychology, 14(8), 1218-1228. 
Table 1. Prevalence of most common news pegs in sample (excluding letters and book reviews)

1 Announcements by ‘childfree’ organisations such as BON (the British Organisation of Non-Parents), the British Childfree Association and Kidding Aside $(n=10)$.

2 Announcement by the Bishop of Rochester about childless couples $(n=7)$.

3 Changes in tax law for couples with children ('pro-parent policy') (n=5).

$4 \quad$ Publication of the book Baby Hunger (Hewitt, 2002) $(n=8)$.

5 Other publications of books, and TV appearances by authors of books, about being childfree or childless $(n=20)$.

$6 \quad$ Publication of various academic or market research studies on childlessness (n $=67)$.

$7 \quad$ Other $(\mathrm{n}=11)$

Final version of published article: Giles, D.C,. Shaw, R.L. \& Morgan, W. (2009). Representaions of voluntary childlessness in the UK Press, 1990-2008. Journal of Health Psychology, 14(8), 1218-1228. 
Table 2. Breakdown of frames identified for longer news items and feature articles

( $\mathrm{VC}=$ voluntary childlessness $)$

1. Individual rights frame $(n=50)$

Right to choose. Here, VC is presented as an individual choice within a broad discourse of individual human rights.

Happily childless. This frame emphasises the benefits of a child-free existence, typically within a discourse of individual self-fulfilment.

Career women. VC either as deliberate choice to protect career ambitions, or as inevitable consequence of career success.

Woman/mother. VC framed as feminist dilemma, often defended with reference to dilemmas of identity.

2. Resistance frame $(n=28)$

Inevitability of children. VC as stance against normative assumption of inevitable parenthood, particularly pertinent for women

Final version of published article: Giles, D.C,. Shaw, R.L. \& Morgan, W. (2009). Representaions of voluntary childlessness in the UK Press, 1990-2008. Journal of Health Psychology, 14(8), 1218-1228. 
Refuseniks. The childless as renegade outgroup, challenging social norms.

Duty to procreate. VC represented as challenge to outmoded or conservative calls to encourage childless couples to have children.

Breeders v childfree. Typically framed as workplace dilemma, with certain allowances made for parents, and childfree as discredited group.

3. Social change frame $(n=24)$

Over-population. VC presented as a socially motivated, altruistic decision based on humanitarian reasoning.

Pro-family legislation. VC explained by economic factors, often as prelude to a call for legislation to encourage couples to have children

Changing society. VC as explained by broad social or historical factors, either with a positive or negative slant.

Family/society breakdown. VC as result of the dissolution of the family unit, typically framed negatively, as 'breakdown'.

Final version of published article: Giles, D.C,. Shaw, R.L. \& Morgan, W. (2009). Representaions of voluntary childlessness in the UK Press, 1990-2008. Journal of Health Psychology, 14(8), 1218-1228. 
4. Personal frame $(n=14)$

Children dilemma. Typically expressed by case studies of couples: Pros and cons of childlessness as an option, often involving a disagreement between partners.

Childless by default. Frame that challenges normative assumption of inevitable parenthood, but not in terms of resistance.

Delayed motherhood. VC represented as temporary phase.

Final version of published article: Giles, D.C,. Shaw, R.L. \& Morgan, W. (2009). Representaions of voluntary childlessness in the UK Press, 1990-2008. Journal of Health Psychology, 14(8), 1218-1228. 


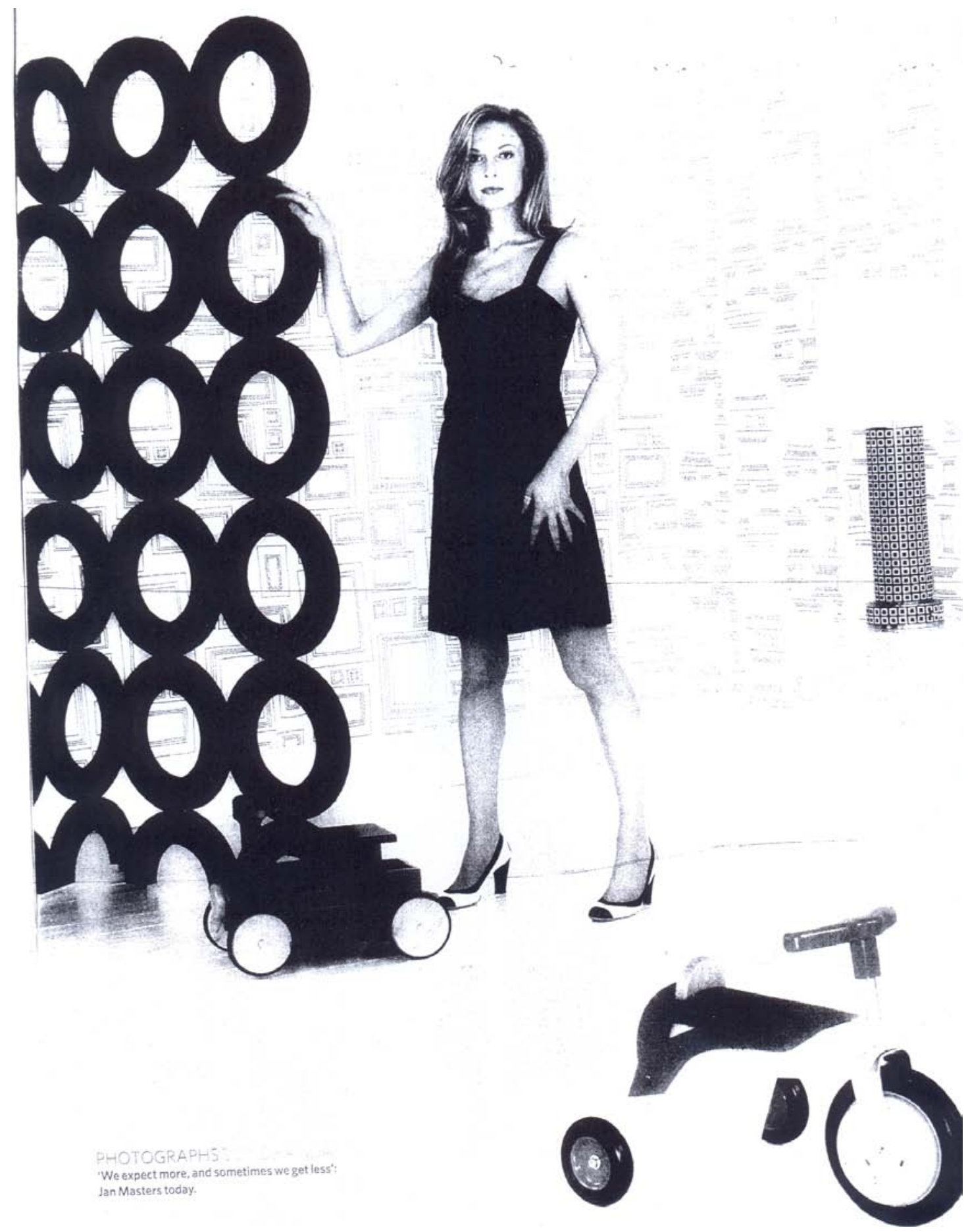

(figure 1)

Final version of published article: Giles, D.C,. Shaw, R.L. \& Morgan, W. (2009). Representaions of voluntary childlessness in the UK Press, 1990-2008. Journal of Health Psychology, 14(8), 1218-1228. 


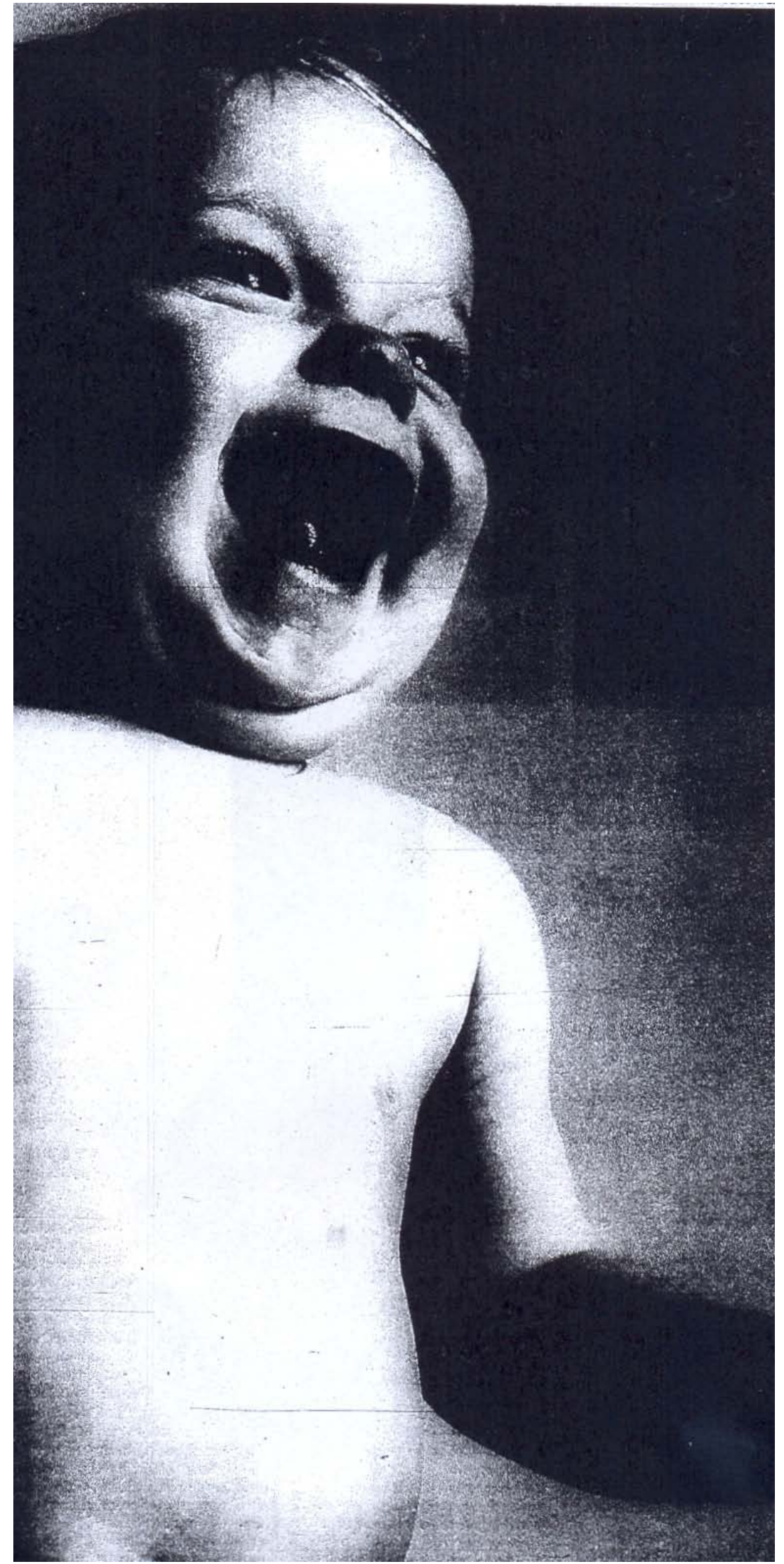

(figure 2)

Final version of published article: Giles, D.C,. Shaw, R.L. \& Morgan, W. (2009). Representaions of voluntary childlessness in the UK Press, 1990-2008. Journal of Health Psychology, 14(8), 1218-1228. 